American Journal of Applied Sciences 6 (7): 1289-1294, 2009

ISSN 1546-9239

(C) 2009 Science Publications

\title{
Effect of Organic Based N Fertilizer on Dry Matter (Zea mays L.), Ammonium and Nitrate Recovery in an Acid Soil of Sarawak, Malaysia
}

\author{
${ }^{1}$ Susilawati Kasim, ${ }^{1}$ Osumanu Haruna Ahmed, ${ }^{1}$ Nik Muhamad Ab. Majid, \\ ${ }^{2}$ Mohd Khanif Yusop and ${ }^{3}$ Mohamadu Boyie Jalloh \\ ${ }^{1}$ Department of Crop Science, Faculty of Agriculture and Food Science, \\ University Putra Malaysia, Bintulu Campus, Sarawak, 97008 Bintulu, Sarawak, Malaysia \\ ${ }^{2}$ Department of Land Management, Faculty of Agriculture, \\ University Putra Malaysia, 43400 Serdang, Selangor, Malaysia \\ ${ }^{3}$ School of Sustainable Agriculture, University Malaysia Sabah, \\ Locked Bag 2073, 88999 Kota Kinabalu, Sabah, Malaysia
}

\begin{abstract}
Problem statement: Exchangeable ammonium $\left(\mathrm{NH}_{4}{ }^{+}\right)$could be recovered by humic and fulvic acids from humic substances. The ability of these acids in fixing or retaining $\mathrm{NH}_{4}{ }^{+}$has been demonstrated in many findings and reports. Both acids could affect the plant growth, nutrients uptake by enhancing photosynthesis rate and root growth among others. Thus, in this study, the effect of both acids (in liquid form) on soil exchangeable $\mathrm{NH}_{4}{ }^{+}$, dry matter production and available nitrate $\left(\mathrm{NO}_{3}{ }^{-}\right.$) was investigated. Approach: Humic molecules were isolated using standard procedures, followed by liquid organic $\mathrm{N}$ fertilizers formulation. Organic based $\mathrm{N}$ fertilizers were applied to soil in pots at 10 Days After Planting (DAP) and 28 DAP. Treated soils and plant parts were sampled at 54 DAP or at tasselling stage. Soil samples were analyzed for $\mathrm{pH}$, ammonium and nitrate content. The plant samples were weighed to assess dry matter production. Results: Under acid condition, organic based liquid $\mathrm{N}$ fertilizers (fulvic acid or both, humic and fulvic acids) increased accumulation of $\mathrm{NH}_{4}{ }^{+}$in soil. The presence of carboxylic groups in humic molecules increased $\mathrm{NH}_{4}{ }^{+}$retention with increasing soil's stock labile carbon. However, low percentage of these acids reduced their full effect on dry matter production. The availability of nitrate was not statistically different for all treatments. Low soil $\mathrm{pH}$ could had reduced nitrification processes and simultaneously soil $\mathrm{NO}_{3}^{-}$content. Conclusion: Liquid form of humic and/or fulvic acids could play an important role in enhancing urea efficiency. However, their contribution needs to be studied in detail in relation to humic molecules characteristics. This study had a potential in the development of liquid and foliar organic fertilizers.
\end{abstract}

Key words: Humic acid, fulvic acid, nitrogen fertilizer, liquid fertilizer, ammonium, nitrate, maize

\section{INTRODUCTION}

In recent times, judicious use of fertilizers vis a vis food safety and environmental pollution is of paramount concern. For instance, unbalanced used of urea (the most commonly used nitrogen fertilizer in agriculture) has created a global environmental issue such as ammonia $\left(\mathrm{NH}_{3}\right)$ volatilization upon surface application $^{[1,2]}$. Thus, a new approach is needed to reduce $\mathrm{NH}_{3}$ loss while improving or increasing Urea-N use efficiency in agriculture.

Ammonia loss is governed by soil factors such as $\mathrm{pH}$, Cation Exchange Capacity (CEC), temperature and moisture $^{[3-5]}$. The amount of $\mathrm{N}$ loss ranges from $10-60 \%$ of the total $\mathrm{N}$ applied ${ }^{[6]}$. With the ever growing concern about the polluting effect of excessive use of nitrogen fertilizers on the environment, improvement of urea-N use efficiency in agriculture cannot be over emphasized. One of the approaches that could be used to improve urea-N use efficiency is to mix it with acidic organic materials such as humic and fulvic acids which have the ability to retain $\mathrm{NH}_{4}{ }^{+}$ions from urea during hydrolysis and at the same time reducing urea $\mathrm{pH}$ during hydrolysis. Some studies have shown positive results regarding the mixture of organic and mineral fertilizers. Increase in total organic carbon and total nitrogen was noted when compost was mixed with mineral fertilizers such as NPK fertilizer. This mixture increased the stock of labile organic carbon ${ }^{[7]}$. Labile organic carbon is known to play an important role in

Corresponding Author: Osumanu Haruna Ahmed, Department of Crop Science, Faculty of Agriculture and Food Sciences, University Putra Malaysia Bintulu Campus, Sarawak, Malaysia Tel: +6086855406 Fax: +608685415 
providing plant nutrients as well as interfering in aggregate stability under favorable conditions ${ }^{[8]}$. Organic substances also have a good effect in controlling $\mathrm{N}$ loss from urea, even in small quantities, thus this attempt was made to evaluate its effectiveness on maize. A previous study showed that Humic Acid (HA) has a great effect in reducing $\mathrm{N}$ loss. For instance the use of $0.75 \mathrm{~g} \mathrm{~kg}^{-1} \mathrm{HA}$ together with zeolite reduced $\mathrm{N}$ loss up to $60 \%{ }^{[9]}$.

Besides being good at controlling $\mathrm{N}$ loss, HA promote plant growth by increasing nutrients (most essential macro and micro nutrients) uptake ${ }^{[10,11]}$. Whilst, humate could give a direct effect to plant photosynthesis, chlorophyll density and plant root respiration, which simultaneously affect and promote plant growth ${ }^{[12]}$.

The objective of this study was to investigate the effect of liquid HA, fulvic acid (FA) and urea mixtures on soil exchangeable $\mathrm{NH}_{4}{ }^{+}$, available $\mathrm{NO}_{3}{ }^{-}$ and dry matter of maize (Zea mays) on Nyalau series (Typic Paleudults).

\section{MATERIALS AND METHODS}

Well decomposed peat (Saprist) soil was sampled $(0-25 \mathrm{~cm})$ from Kuala Tatau, Sarawak, Malaysia whilst the mineral soil used in this study was taken from an undisturbed area of University Putra Malaysia Bintulu Campus, Sarawak at a depth of $0-25 \mathrm{~cm}$. Both soils were air dried and sieved to pass through $2 \mathrm{~mm}$ sieve for further analysis and glasshouse study. Prior to chemical analysis, the peat samples were oven dried at $60^{\circ} \mathrm{C}$ for $24 \mathrm{~h}$. The mineral soil was analyzed for $\mathrm{pH}$ (water and $\mathrm{KCl}$ ) at a ratio of 1:2.5 using glass electrode, CEC by leaching with $1 \mathrm{~N}$ ammonium acetate (adjusted to $\mathrm{pH}$ 7) followed with steam distillation technique ${ }^{[13]}$, exchangeable cations ( $\mathrm{K}, \mathrm{Ca}$ and $\mathrm{Mg}$ ) by atomic absorption spectrophotometry (A Analyst 800, Perkin Elmer Instruments, Norwalk, CT), total $\mathrm{N}$ by the Micro-kjeldahl method, organic matter and total organic carbon by combustion method ${ }^{[14]}$ and bulk density was determined using standard procedures ${ }^{[15]}$.

A modified method by Susilawati et al. ${ }^{[16]}$ was used to isolate HA and FA of peat for fertilizer formulation. Since HA isolation involves acidification processes to separate humic and fulvic acids using $6 \mathrm{~N} \mathrm{HCl}$, two types of mixtures were made and they were acidified and unacidified mixtures. Both mixtures contained humic and fulvic acids.

A glasshouse study was conducted using a completely randomized block design with 3 replications. There were 8 treatments selected for testing in this study. The treatments evaluated were: Liquid urea $\left(\mathrm{T}_{1}\right)$, solid urea $\left(\mathrm{T}_{2}\right)$, urea + liquid HA $\left(\mathrm{T}_{3}\right)$, urea + liquid FA
$\left(\mathrm{T}_{4}\right)$, urea + liquid mixture of acidified HA $+\mathrm{FA}\left(\mathrm{T}_{5}\right)$, urea + liquid mixture of unacidified $\mathrm{HA}+\mathrm{FA}\left(\mathrm{T}_{6}\right)$, liquid ammonium sulphate $\left[\left(\mathrm{NH}_{4}\right)_{2} \mathrm{SO}_{4}\right]\left(\mathrm{T}_{7}\right)$ and control (soil without any treatments) $\left(\mathrm{T}_{0}\right)$. A total of $7.5 \mathrm{~kg}$ soil (based on the bulk density of the soil) was weighed into each plastic pots measuring $27 \times 18 \mathrm{~cm}$.

The fertilizer requirement of the maize crop (330.4 $\mathrm{kg} \mathrm{ha}^{-1}$ urea; $121.6 \mathrm{~kg} \mathrm{ha}^{-1} \mathrm{TSP} ; 107.2 \mathrm{~kg} \mathrm{ha}^{-1}$ MOP) was scaled down to per pot basis equivalent to: Urea (4.13 $\left.\mathrm{g} \mathrm{pot}^{-1}\right)$, triple superphosphate (TSP) (1.52 $\mathrm{g} \mathrm{pot}$ pot $^{-1}$ and Murate Of Potash (MOP) $\left(1.34 \mathrm{~g} \mathrm{pot}^{-1}\right)$. These fertilizers were surface applied ten days after planting (DAP) and 28 DAP. The plants were monitored up to tassel stage (54 DAP) before harvest, because tassel stage is the maximum growth stage the plant can achieve before it goes to productive stage. The shoots of the plants were harvested and partitioned into leaf and stem. The remaining roots in the soil were collected by washing the soil from the roots using tap water. The plant parts were oven dried at $60^{\circ} \mathrm{C}$ to constant weight and weighed using a digital balance. Prior to harvesting, soil samples were taken from the pots and analyzed for $\mathrm{pH}$, exchangeable $\mathrm{NH}_{4}{ }^{+}$and available $\mathrm{NO}_{3}^{-}$using standard method.

Analysis of variance was used to test treatment effects while means of treatments were compared using Duncan's New Multiple Range Test (DNMRT) ${ }^{[17]}$.

\section{RESULTS}

The soil used in this study was acidic, in both water and $\mathrm{KCl}$ (Table 1). The CEC of the soil was consistent with that reported for Nyalau series by Paramanathan ${ }^{[18]}$ (Table 1). Nitrogen content in this soil was low but those of organic matter and total organic carbon were relatively high (Table 1). The bulk density of the soil was 1.548 .

Table 1: Physico-chemical characteristics of Nyalau series

\begin{tabular}{lcl}
\hline Property & $\begin{array}{l}\text { Value } \\
\text { obtained } \\
(0-25 \mathrm{~cm})\end{array}$ & $\begin{array}{l}\text { Standard } \\
\text { data range* } \\
(0-35 \mathrm{~cm})\end{array}$ \\
\hline $\mathrm{pH}_{\mathrm{w}}$ & 4.290 & $4.7-4.8$ \\
$\mathrm{pH}_{\mathrm{KCl}}$ & 3.570 & $4.0-4.2$ \\
Exchangeable $\mathrm{K}^{+}\left(\mathrm{cmoL} \mathrm{kg}^{-1}\right)$ & 0.180 & $0.09^{*}$ \\
${\text { Exchangeable } \mathrm{Ca}^{2+}\left(\mathrm{cmoL} \mathrm{kg}^{-1}\right)}_{\text {Exchangeable } \mathrm{Mg}^{2+}\left(\mathrm{cmoL} \mathrm{kg}^{-1}\right)}^{2.260}$ & $0.05^{*}$ \\
CEC $\left(\mathrm{cmoL} \mathrm{kg}^{-1}\right)$ & 2.980 & $<0.01^{*}$ \\
Total nitrogen $(\%)$ & 24.500 & $24.6-53.5$ \\
Total organic carbon (\%) & 0.340 & $0.03-0.06^{*}$ \\
Organic matter $(\%)$ & 3.350 & $0.69-1.30^{*}$ \\
C/N ratio & 5.780 & $1.12-2.24^{*}$ \\
Bulk density & 9.850 & $22-23^{*}$ \\
Clay (\%) & 1.548 & $\mathrm{nd}$ \\
Sand (\%) & 22.840 & $11-14^{*}$ \\
Silt $(\%)$ & 58.520 & $78-81^{*}$ \\
\hline
\end{tabular}

*: Subject to the soil development, standard data range by Paramananthan $^{[18]}$ 
Am. J. Applied Sci., 6 (7): 1289-1294, 2009

Table 2: Effect of treatments on soil $\mathrm{pH}$ at $54 \mathrm{DAP}$

\begin{tabular}{llll}
\hline Label & Treatment & $\mathrm{pH}_{\mathrm{w}}$ & $\mathrm{pH}_{\mathrm{KCl}}$ \\
\hline $\mathrm{T}_{0}$ & Control (without urea fertilizer) & $4.47^{\mathrm{b}}$ & $3.65^{\mathrm{b}}$ \\
$\mathrm{T}_{1}$ & Liquid urea & $4.58^{\mathrm{ab}}$ & $3.68^{\mathrm{ab}}$ \\
$\mathrm{T}_{2}$ & Solid urea & $4.63^{\mathrm{ab}}$ & $3.66^{\mathrm{ab}}$ \\
$\mathrm{T}_{3}$ & Urea + liquid HA & $4.44^{\mathrm{b}}$ & $3.60^{\mathrm{b}}$ \\
$\mathrm{T}_{4}$ & Urea + liquid FA & $4.63 \mathrm{a}^{\mathrm{b}}$ & $3.72^{\mathrm{ab}}$ \\
$\mathrm{T}_{5}$ & Urea + liquid of HA + FA (acidified) & $4.70^{\mathrm{a}}$ & $3.78^{\mathrm{a}}$ \\
& Urea + liquid of HA + FA (unacidified) & & \\
$\mathrm{T}_{6}$ & Liquid ( $\left.\mathrm{NH}_{4}\right)_{2} \mathrm{SO}_{4}$ & $4.56 \mathrm{a}^{\mathrm{b}}$ & $3.68^{\mathrm{ab}}$ \\
& & & \\
$\mathrm{T}_{7}$ & & $4.13^{\mathrm{c}}$ & $3.60^{\mathrm{b}}$ \\
\hline
\end{tabular}

Different letters indicate significant difference between means using Duncan's New Multiple Range Test (DNMRT) at $\mathrm{p}=0.05$

Table 3: $\mathrm{pH}$ values of formulated liquid organic-urea mixture fertilizer

\begin{tabular}{llll}
\hline & & $\mathrm{pH}$ & \\
& & ----1 & \\
Code & Treatment & Without urea & With urea \\
\hline $\mathrm{F}_{1}$ & Urea (liquid) & Nd & 8.14 \\
$\mathrm{~F}_{2}$ & $\mathrm{HA}$ & 1.89 & 9.04 \\
$\mathrm{~F}_{3}$ & $\mathrm{FA}$ & 1.02 & 1.64 \\
$\mathrm{~F}_{4}$ & $\mathrm{HA}+$ FA (acidified) & 0.98 & 1.60 \\
$\mathrm{~F}_{5}$ & $\mathrm{HA}+\mathrm{FA}$ (unacidified) & 6.56 & 6.89 \\
\hline
\end{tabular}

Table 4: Effect of treatments on dry matter production of maize at 54 DAP

\begin{tabular}{llc}
\hline & & \\
Label & Treatment & $\begin{array}{c}\text { Total dry } \\
\text { weight }(\mathrm{g})\end{array}$ \\
\hline $\mathrm{T}_{0}$ & Control (without urea fertilizer) & $12.92^{\mathrm{b}}$ \\
$\mathrm{T}_{1}$ & Liquid urea & $123.75^{\mathrm{a}}$ \\
$\mathrm{T}_{2}$ & Solid urea & $125.67^{\mathrm{a}}$ \\
$\mathrm{T}_{3}$ & Urea + liquid HA & $107.59^{\mathrm{a}}$ \\
$\mathrm{T}_{4}$ & Urea + liquid FA & $110.42^{\mathrm{a}}$ \\
$\mathrm{T}_{5}$ & Urea + liquid of HA + FA (acidified) & $106.94^{\mathrm{a}}$ \\
$\mathrm{T}_{6}$ & Urea + liquid of HA + FA (unacidified) & $117.47^{\mathrm{a}}$ \\
$\mathrm{T}_{7}$ & Liquid ( $\left.\mathrm{NH}_{4}\right)_{2} \mathrm{SO}_{4}$ & $34.57^{\mathrm{b}}$ \\
\hline Different letters indicate significant difference between means using \\
Duncan's New Multiple Range Test (DNMRT) at $\mathrm{p}=0.05$
\end{tabular}

Except for $\mathrm{T}_{5}$ and $\mathrm{T}_{7}\left(\mathrm{pH}_{\mathrm{w}}\right)$ and $\mathrm{T}_{5}\left(\mathrm{pH}_{\mathrm{KCl}}\right)$, the $\mathrm{pH}$ of the treatments were not statistically different from $\mathrm{T}_{0}$ (control) at 54 DAP (Table 2). This suggests that soil treated with urea, or mixture of urea with liquid organic materials does not significantly change $\mathrm{pH}$ values. As expected, the lowest $\mathrm{pH}$ was recorded from $\mathrm{T}_{7}$ treatment. As shown in Table 2, application of high $\mathrm{pH}$ fertilizer (Table 3) for some of the treatments did not show any significant effect on $\mathrm{pH}$ (water and $\mathrm{KCl}$ ).

The dry matter production of the test crop was superior for the treatment with liquid organic fertilizer $\left(\mathrm{T}_{3}-\mathrm{T}_{6}\right)$ and urea $\left(\mathrm{T}_{1}\right.$ and $\left.\mathrm{T}_{2}\right)$, compared to $\left(\mathrm{NH}_{4}\right)_{2} \mathrm{SO}_{4}$ $\left(\mathrm{T}_{7}\right)$ and control $\left(\mathrm{T}_{0}\right)$ (Table 4). Even though, the HA containing fertilizers recorded highest $\mathrm{pH}$ as compared to other treatments (Table 3 ), the dry matter production under this treatment was not statistically different from others. This observation is particularly consistent with the result of $\mathrm{T} 6$, whose $\mathrm{pH}$ was 6.89 .
Ammonium sulphate $\left[\left(\mathrm{NH}_{4}\right)_{2} \mathrm{SO}_{4}\right]$ is also an important $\mathrm{N}$ fertilizer in agriculture. However, in this study it failed to improve dry matter production compared to the other treatments although the concentration of $\mathrm{NH}_{4}{ }^{+}$under this treatment was the highest (Fig. 1).

In terms of $\mathrm{NH}_{4}{ }^{+}$accumulation, $\mathrm{T}_{4}$ and $\mathrm{T}_{5}$ were more effective (Fig. 1) compared to the other treatments except for $\mathrm{T}_{7}$. Generally, soil available $\mathrm{NO}_{3}{ }^{-}$was the same for all the treatments applied, except for $\mathrm{T}_{7}$ and $\mathrm{T}_{0}$ (Fig. 2).

\section{DISCUSSION}

The difference in exchangeable cations $(\mathrm{K}, \mathrm{Ca}$ and $\mathrm{Mg}$ ), clay, sand and silt contents were probably due to differences in soil horizon. The presence of either cambic (unclear horizon with some changes in physical and chemical properties) or argillic (accumulation of clay silicate and present of clay in pad surface) horizon leads to different results in certain soil properties of Nyalau series. However, a comparison could not be made due to lack of information for the Nyalau series data with cambic, instead of argillic (reported in Paramananthan $^{[18]}$.

The liquid form of fertilizer applied could be one of the reasons for the low $\mathrm{pH}$. High mobility of fertilizer fractions would enhance fertilizer loss, through water or air movement and hence less effect on $\mathrm{pH}$. In this study, the fertilizers could not give long term effect on $\mathrm{pH}$. The low $\mathrm{pH}$ of the soil treated with organic based $\mathrm{N}$ fertilizers $\left(\mathrm{F}_{1}-\mathrm{F}_{5}\right)$ does not necessarily suggest that those treatments did not increase or decrease the $\mathrm{pH}$ of the soil. Their effect could be temporary as reported by Ahmed et al.$^{[19]}$ where a short term effect of urea mixed with acidic materials temporarily reduced soil $\mathrm{pH}$.

The tendency of HA to react with $\mathrm{NH}_{3}$, released by urea, was high in the formulated fertilizers consisting HA. Hydrolysis of urea, which increased the surrounding $\mathrm{pH}$ could promote the reaction to occur. The presence of high $\mathrm{NH}_{3}$ due to continuos hydrolysis of urea and overload of $\mathrm{NH}_{4}{ }^{+}$could enhance fixation processes ${ }^{[20]}$.

The acidic nature of $\left(\mathrm{NH}_{4}\right)_{2} \mathrm{SO}_{4}$ reduced its effect on dry matter production. This acidity without liming may cause poor plant growth and development. The sulfur, in the form of sulphate $\left(\mathrm{SO}_{4}{ }^{2-}\right)$ reduces soil $\mathrm{pH}$ and affects $\mathrm{NH}_{3}$ volatilization ${ }^{[21]}$. Thus, $\left(\mathrm{NH}_{4}\right)_{2} \mathrm{SO}_{4}$ seems not suitable for use in acid soils.

Functional groups present in humic molecules together with its characteristics produced a lot of effects on $\mathrm{NH}_{4}{ }^{+}$recovery. Less oxygen containing functional 
groups present in HA as compared to FA reduced soil exchangeable $\mathrm{NH}_{4}{ }^{+}$in $\mathrm{T}_{4}$. The ability of carboxylic groups to dissociate their protons at $\mathrm{pH} 3^{[22]}$ however, may have enabled the humic molecules (especially FA) to retain more $\mathrm{NH}_{4}{ }^{+}$at this low $\mathrm{pH}$. Hence, this partly explains why $\mathrm{T}_{5}$ recorded more $\mathrm{NH}_{4}{ }^{+}$in soil at 54 DAP. The low cation exchange capacity (total acidity) of HA could be one of the reasons for inefficiency of HA. According to $\mathrm{Tan}^{[22]}$, the total acidity of HA varies from 6-8.9 meq $\mathrm{g}^{-1}$ while that of FA, ranges between 10 and $12.3 \mathrm{meq} \mathrm{g}^{-1}$. Thus, FA could perform better in acid soil to enhance urea efficiency through $\mathrm{NH}_{4}{ }^{+}$retention.

The formulated fertilizers, $T_{4}$ and $T_{5}$ were acidic (Table 3: $\mathrm{F}_{3}$ and $\mathrm{F}_{4}$ ). Treated soil with $\mathrm{T}_{4}$ and $\mathrm{T}_{5}$ may cause soil to be acidic hence reduction of $\mathrm{N}$ loss through volatilization. Thus, in this study, these treatments recorded more exchangeable $\mathrm{NH}_{4}{ }^{+}$as compared to others. Similar results have been reported by Fan $e t a l .{ }^{[23]}$, where they found that the use of TSP (more acidic) reduced $\mathrm{NH}_{3}$ volatilization from urea as compared to monoammonium phosphate (MAP).

Basically, total $\mathrm{N}$ and $\mathrm{C}: \mathrm{N}$ ratio values could indicate $\mathrm{NH}_{4}{ }^{+}$fixation by soils. For instance, total $\mathrm{N}$ of $0.29 \%$ with C: $\mathrm{N}$ ratio of 10.4 could fix $125 \mu \mathrm{g} \mathrm{g}^{-1}$ of $\mathrm{NH}_{4}{ }^{+}$in soils ${ }^{[20]}$. The possibility of these processes to occur was high in treated soil with total $\mathrm{N}$ of $0.34 \%$ and C: $\mathrm{N}$ ratio of 9.85 . However, its contribution could not be significant between treatments because the soils in this study received the same amount of $\mathrm{N}$ due to this process. This is clearly demonstrated in Fig. 1 and 2 and dry matter production (Table 3 ).

Inefficiency of $\mathrm{HA}$ in enhancing $\mathrm{N}$ recovery and dry matter production was recorded in this study. The low amount of HA used in fertilizer formulation could be a significant factor. The HA used was much lower as compared to the soil (0.16 g HA used/7.5 kg soil). Since, humic substances are believed to contain a very small amount of permanent charges which are responsible for CEC development with $10 \%$ estimation from its total negative charges ${ }^{[24,25]}$, its contribution to cations retention would be subjective and relying on its quantity used. However, at this small percentage, HA still showed significant difference $(\mathrm{p}=0.05)$ of soil exchangeable $\mathrm{NH}_{4}{ }^{+}$as compared to T1 and T2.

Insignificant difference in $\mathrm{NO}_{3}^{-}$content could probably be due to low soil $\mathrm{pH}$, which reduces nitrification processes. Based on a previous report, the optimum $\mathrm{pH}$ for this process to take place is $8.5^{[3]}$. At the $\mathrm{pH}$ range of this study, this process could not progressively occur thus, causing low soil $\mathrm{NO}_{3}^{-}$ content.

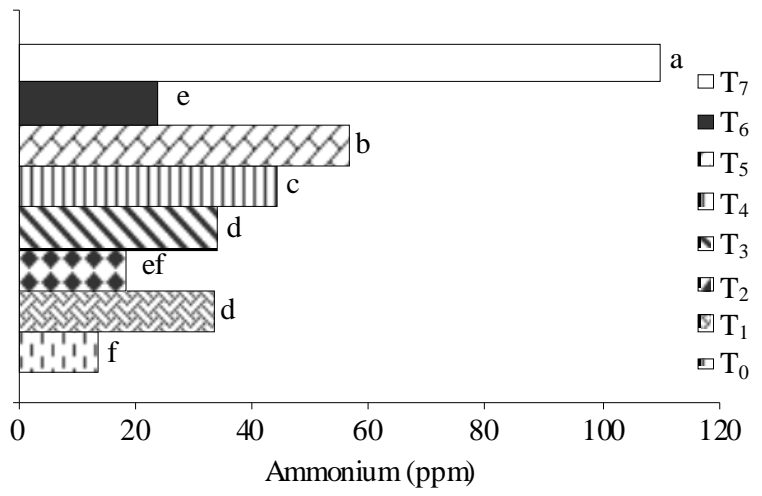

Fig. 1: Effect of treatments on soil exchangeable ammonium at 54 DAP. (Different letter indicate significant difference between means using Duncan's New Multiple Range Test (DNMRT) at $\mathrm{p}=0.05$ )

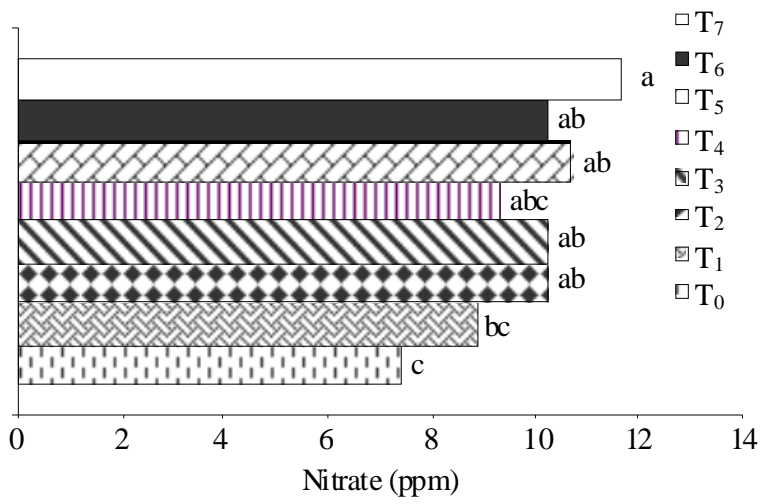

Fig. 2: Effect of treatments on soil available nitrate at 54 DAP. (Different letter indicate significant difference between means using Duncan's New Multiple Range Test (DNMRT) at $\mathrm{p}=0.05$ )

\section{CONCLUSION}

Liquid form of humic and/or fulvic acids could play an important role in enhancing urea efficiency. However, their contribution needs to be studied in detail in relation to humic molecule characteristics. The amount or rate of humic molecules to enhance $\mathrm{NH}_{4}{ }^{+}$ and $\mathrm{NO}_{3}{ }^{-}$recovery in soil which can indirectly promote plant growth needs detail investigation. This study has the potential to be advanced especially in terms of liquid organic fertilizer development. Liquid organic fertilizer has a big potential to be used as foliar fertilizer in the future. 


\section{ACKNOWLEDGEMENT}

The researchers acknowledge the financial support for this research by the Ministry of Higher Education Malaysia.

\section{REFERENCES}

1. Prasertsak, P., J.R. Freney, P.G. Saffiga, O.T. Denmead and B.G. Prove, 2001. Fate of urea nitrogen applied to a banana crop in the wet tropics of Queensland. Nutr. Cycl. Agroecosyst. 59: 65-73. DOI: 10.1023/A:1009806826141

2. Cai, G.X., D.L. Chen, H. Ding, A. Pacholski, X.H. Fan and Z.L. Zhu, 2002. Nitrogen losses from fertilizers applied to maize, wheat and rice in the North China Plan. Nutr. Cycl. Agroecosyst. 63: 187-195. DOI: 10.1023/A:1021198724250

3. Havlin, J.L., J.D. Beaton, S.M. Tisdale and W.L. Nelson, 1999. Nitrogen. In: Soil Fertility and Fertilizers: An Introduction to Nutrient Management, 6th Edn., Prentice Hall, Inc., Upper Saddle River, New Jersey, USA., ISBN: 0136268064, pp: 86-153.

4. Nelson, D.W., 1982. Gaseous Loss of Nitrogen other than Through Denitrification. In: Nitrogen in Agricultural Soils, Stevenson, F.J. (Ed.). American Society of Agronomy, Monograph, ISBN: 0891180702 pp: 123.

5. Al-Kanani, T., A.F. MacKenzie and N.N. Barthakur, 1991. Soil water and ammonia volatilization relationships with surface-applied nitrogen fertilizer solutions. Soil Sci. Soc. A. J., 55: 1761-1766. http://soil.scijournals.org/cgi/reprint/55/6/1761

6. Fillery, R.P. and S.K. De Datta, 1986. Ammonia volatilization from nitrogen sources applied to rice field: 1. Methodology, ammonia fluxes and nitrogen N-15 loss. Soil Sci. Soc. Am. J., 50: 80-86. http://soil.scijournals.org/cgi/reprint/50/1/80

7. Leite, L.F.C., E.S. Mendonca and P.L.O.A. Machado, 2007. Influence of organic and mineral fertilisation on organic matter fractions of Brazilian Acrisol under maize/common bean intercrop. Aust. J. Soil Res., 45: 25-32. DOI: 10.1071/SR06029

8. Whitebread, A., R.D.B. Lefroy and G.J. Blair, 1998. A survey of the impact of cropping on soil physical and chemical properties in north-western New South Wales. Aust. J. Soil Res., 36: 669-681. DOI: $10.1071 /$ S97031

9. Ahmed, O.H., H. Aminuddin and M.H.A. Husni, 2006. Effects of urea, humic acid and phosphate interactions in fertilizer microsites on ammonia volatilization and soil ammonium and nitrate contents. Int. J. Agric. Res., 1: 25-31. DOI: 10.3923/ijar.2006.25.31
10. Adani, F., P. Genevini, P. Zaccheo and G. Zocchi. 1998. The effect of commercial humic acid on tomato plant growth and mineral nutrition. J. Plant Nutr., $\quad 21$ : $561-575 . \quad$ DOI: 10.1080/01904169809365424

11. David, P.P., P.V. Nelson, D.C. Sanders, 1994. A humic acid improves growth of tomato seedling in solution culture. J. Plant Nutr. 17: 173-184. DOI: 10.1080/01904169409364717

12. Chen, Y. and T. Aviad, 1990. Effects of Humic Substance on Plant Growth. In: Humic Substances in Soil and Crop Sciences: Selected Readings, MacCarthy, P., C.E. Clapp, R.L. Malcolm and P.R. Bloom (Eds.). Soil Science Society of America, Madison, Wisconsin, ISBN: 0891181040 9780891181040, pp: 161-186.

13. Keeney, D.R. and D.W. Nelson, 1982. NitrogenInorganic Forms. In: Methods of Soil Analysis, Part 2, Page, A.L., D.R. Keeney, D.E. Baker, R.H. Miller, R. Jr. Ellis and J.D. Rhoades (Eds.). 2nd Edn., Agron. Monogr. 9. ASA and SSSA, Madison, WI. ISBN: 0891180729 (pt. 2).

14. Cheftetz, B., P.H. Hatcher, Y. Hadar and Y. Chen, 1996. Chemical and biological characterization of organic matter during composting of municipal solid waste. J. Environ. Qual., 25: 776-785. http://jeq.scijournals.org/cgi/reprint/25/4/776

15. Tan, K.H., 2005. Determination of Soil Water. In: Soil Sampling, Preparation and Analysis, 2nd Edn., CRC Press, Taylor and Francis Group, USA., ISBN: 0849334993.

16. Susilawati, K., O.H. Ahmed, A.B. Nik Muhamad and M. Y. Khanif, 2007. Effects of extraction and fractionation period on the yield of a tropical peat soil (Hemists) humic acids. Am. J. Agric. Biol. Sci., 2: 202-205. http://www.scipub.org/fulltext/AJAB/AJAB23202205.pdf

17. SAS., 2001. SAS/STAT Software. SAS Institute, Cary, NC. ISBN: 10: 1580258506.

18. Paramananthan, S., 2000. Soils of Malaysia: Their Characteristics and Identification. Vol. 1. Academy of Sciences Malaysia, Kuala Lumpur. ISBN: 9839445065.

19. Ahmed, O.H., H, Aminuddin, M.H.A. Husni, A.R. Anuar and A.M. Nik Muhamad, 2008. Enhancing the urea-N use efficiency in Maize (Zea mays) cultivation on acid soils amended with zeolite and TSP. TheScientificWorld J., 8: 394-399. DOI: $10.1100 /$ tsw.2008.68 
20. Stevenson, F.H., 1994. Humus Chemistry: Genesis, Composition, Reactions. 2nd Edn., Wiley, New York, ISBN: 0471594741, pp: 378-486.

21. Zaman, M., M.L. Nguyen, J.D. Blennerhassett and B.F. Quin, 2007. Reducing NH3, N2O and NO3$\mathrm{N}$ losses from a pasture soil with urease or nitrification inhibitors and elemental S-amended nitrogenous fertilizers. Biol. Fertil., 44: 693-705. Soils, DOI: 10.1007/s00374-007-0252-4

22. Tan, K.H., 2003. Humic Matter in Soil and the Environment: Principles and Controversies. Marcel Dekker, Inc., New York, ISBN: 0-8247-4272-9, pp: 34-71.

23. Fan, M.X., A.F. MacKenzie and H.D. Blenkhorn, 1996. A modified urea based NP fertilizer: ureaTSP-MAP combinations. Fertil. Res., 45: 217-220. DOI: $10.1007 / \mathrm{BF} 00748592$
24. Brady, N.C., 1990. The Nature and Properties of Soils. 10th Edn., Macmillan Publ. Co., New York, ISBN: 0023133619.

25. Tan, K.H., D.S. Himmelsbach and J.C. Lobartini, 1992. The significance of solid-state ${ }^{13} \mathrm{C}$ NMR spectroscopy of whole soil in the characterization of humic matter. Commun. Soil Sci. Plant Anal., 23: 1513-1532. DOI: 10.1080/00103629209368684 